\title{
Taxpayer Perception, Implementation of SME's Accounting, Self Assessment System and Income Level to Compliance with SME's Taxpayers
}

\author{
Yulinda Devi Pramita ${ }^{1}$, Nur Laila Yuliani ${ }^{2}$ \\ \{yulinda.feb@ummgl.ac.id ${ }^{1}$ \} \\ Accounting, Universitas Muhammadiyah Magelang, Indonesia ${ }^{1,2}$
}

\begin{abstract}
The implementation of PP No. 23 tahun 2018 is a strategic step taken by the government in an effort to increase and optimize income tax collection. The reason behind the goal of the SME's income tax policy is that the contribution of SME's to the economy is very large, but the contribution of SME's in taxation revenue is very small. Several strategic steps have been taken by the government through the DJP, including the ease and simplification of tax treatment for SME's businesses and determining the cost taxation according to the capabilities of SME's. The self-assessment system in reality, the system is difficult to run as expected and has the potential for abuse. The research data used as a sample of 58 questionnaires filled out by owners/ managers of SME's in Magelang City who already have a NPWP. The test results show that the Taxpayers' Perceptions of Government Regulation PP No. 23 tahun 2018 and the Self Assessment System have a significant positive effect on SME Taxpayer Compliance in Magelang City. Meanwhile, the application of accounting for SME's and income levels has no effect on SME's taxpayer compliance in Magelang City. The implication of this research is the importance of understanding tax regulations and knowledge of the self-assessment system for SME's so that it will further improve compliance with paying SME's taxes in a conscious manner without any pressure from regulations.
\end{abstract}

Keywords: Taxpayer perception, self assessment, compliance

\section{Introduction}

Taxes are contributions to the state which are enforceable and payable by taxpayers who have met the provisions of subjective and objective requirements according to law. The tax paid is used to finance general expenses related to government administration. The largest source of state revenue in fulfilling state spending at this time comes from tax revenue. Almost every year in the preparation of the State Expenditure Budget, more than $80 \%$ of revenue originating from taxes is used to meet budget financing needs. The government has set a fiscal mission so that development planning continues, with taxes as a strategic component [1]. Therefore, the active role and awareness of taxpayers is needed in increasing the source of state revenue. Concern in paying taxes will be difficult to realize if there are no elements that can be enforced. This element provides an understanding that people are required to pay taxes voluntarily and with full awareness of being good citizens [2].

The Indonesian government through the Directorate General of Taxes (DGT) has issued PP No. 23 of 2018 as a substitute for PP No. 46 of 2013 concerning Income Tax on Income from 
Business Received or Obtained by Taxpayers who have Gross Turnover. One of the most significant changes from the enactment of PP. 23 of 2018 is the tax rate for MSME businesses, which was originally $1 \%$ to $0.5 \%$ of the total gross turnover. With this implementation, it is hoped that it will reduce the pros and cons problems related to taxpayer compliance in fulfilling their tax obligations. The implementation of PP 23 of 2018 is a strategic step taken by the government in an effort to increase and optimize income tax collection. The reason behind the goal of the MSME income tax policy is that the contribution of MSMEs to the economy is very large, but the contribution of MSMEs in taxation revenues is very small. Several strategic steps have been taken by the government through the DGT, including the ease and simplification of tax treatment for MSME businesses and determining the tax burden according to the capabilities of MSMEs.

Many innovations have been carried out by the Directorate General of Taxes to make it easier for taxpayers to participate in developing the country. If income taxpayer compliance increases, tax revenue will increase so that the state treasury will also increase [3]. According to [4], the self assessment system is not a voluntary system but rather a tax system that relies on taxpayers to report their income freely and voluntarily, calculate their tax obligations correctly and report, submit tax returns in a timely manner. However, in reality, the system is difficult to run as expected and has the potential for abuse. The self-assessment system in taxation has an important role in increasing taxpayer compliance.

This research refers to research conducted by [5]. The difference between this study and previous research is the analysis of the perceptions and understanding of taxpayers on the implementation of PP. 23 of 2018 in lieu of PP No. 46 of 2013 with the new rate of $0.5 \%$ which is intended to motivate taxpayers to pay income tax from independent business operations. Other variables examined in this study are the application of MSME accounting, the self-assessment system enforced by the DGT, and the level of income earned by MSME business actors towards UMKM taxpayer compliance. This research was conducted with a sample of UMKM taxpayers registered at KPP Pratama Magelang in 2018. The increasing number of MSME business players in Magelang City did contribute to tax revenue originating from MSME income tax.

\section{Method}

The sampling method is purposive sampling, which is sampling based on certain criteria [6]. The sample used in this study were MSME taxpayers registered at KPP Pratama Magelang who were active in 2018. Their business was formalized as a taxable entrepreneur. Active MSMEs are still running a business and doing bookkeeping. Have a turnover of less than 4.8 billion in a year.

The type of research data is primary data in the form of a research questionnaire. The data collection method was carried out through a survey. Questionnaires from respondents are selected first in order to get a completely filled questionnaire. The list of questions (questionnaire) in this study refers to a research questionnaire tailored to the situation, related theories.

a. MSME Taxpayer Compliance Taxpayer compliance is a condition in which taxpayers carry out their tax obligations properly and voluntarily.

b. Taxpayers' Perceptions of the Enactment of PP No.23 of 2018 
The taxpayer's perception is a condition in which the taxpayer understands and responds to the implementation of taxation rules that are enforced.

c. MSME Accounting Application

The application of accounting for MSMEs is that taxpayers run their business based on proper and correct bookkeeping.

d. Self Assessment System

The self-assessment system is a system that gives taxpayers the authority to calculate, deposit and report their tax obligations themselves.

e. Income

Tax collection must be submitted at the right time, namely when the taxpayer receives income. This is intended so that taxpayers are said to be able to fulfill their tax obligations.

The regression equation used is as follows:

$\mathrm{Y}=\alpha+\beta_{1} \mathrm{PWP}+\beta_{2} \mathrm{PA}+\beta_{3} \mathrm{SSA}+\beta_{4} \mathrm{TP}+\mathrm{e}$

Where $\mathrm{Y}=$ Taxpayer Compliance; $\alpha=$ Constant; $\beta_{1,2,3,4}=$ Regression coefficient; PWP = Perception of taxpayers on the implementation of PP No.23 of 2018; PA = Application of MSME accounting; SSA = Self Assessment System, and TP = Income Level

\section{Results and Discussion}

\subsection{Results}

Based on the table R square and F test showed on Table 1 and 2.

Table 1. R square

\begin{tabular}{ccccc}
\hline Model & $\mathrm{R}$ & $\mathrm{R}$ Square & Adjusted R Square & Std. Error of the Estimate \\
\hline 1 &, $784^{\mathrm{a}}$ &, 615 &, 586 &, 283 \\
\hline $\begin{array}{l}\text { a. Predictors: (Constant), TP, PWP, SSA, PA } \\
\text { Dependent Variable: KWP }\end{array}$
\end{tabular}

Based on the table above, the R2 value or the coefficient of determination is 0.586 . This means that the independent variable of taxpayer perceptions related to PP No. 23 of 2018, the application of SME accounting, the self-assessment system and the level of income have an effect of $58.6 \%$ on the dependent variable of SME taxpayer compliance. Meanwhile, $41.4 \%$ was influenced by other variables not included in the regression model.

Table 2. F test

\begin{tabular}{llllll}
\hline Model & Sum of Squares & Df & Mean Square & F & Sig. \\
\hline
\end{tabular}




\begin{tabular}{llllll}
\hline Regression & 6,774 & 4 & 1,693 & 21,131 &, $000 \mathrm{~b}$ \\
Residual & 4,248 & 53 &, 080 & & \\
Total & 11,022 & 57 & & & \\
\hline
\end{tabular}

The F statistical test is basically used to measure the accuracy of the sample regression function in estimating the actual value (goodness of fit). The F test tests whether the independent variable is able to explain the dependent variable well or to test whether the model used is fixed or not. Based on table 4.9, F count $>\mathrm{F}$ table or $\mathrm{p}$ value $<\alpha=0.05$, meaning that the model used is good (fit).

Partial testing is used to determine whether the independent variable individually has an influence on the dependent variable. Based on table 4.10, the results of the t test show Taxpayers' Perceptions of Government Regulation No. 23 of 2018 and the Self Assessment System have a significant positive effect on SME Taxpayer Compliance in Magelang City so that H1 and H3 of this study are accepted. While the application of accounting for SMEs and income levels does not affect SME taxpayer compliance in Magelang City, $\mathrm{H} 2$ and $\mathrm{H} 4$ research is not accepted.

\subsection{Discussion}

Taxpayers' Perceptions of PP. 23 of 2018 has a positive effect on SME Taxpayer Compliance. This means that the better the perception of taxpayers on tax regulations, especially PP. 23 of 2018 will increase SME taxpayer compliance. This implies that SMEs in Magelang City need socialization related to tax regulations so that it will motivate to comply with tax payments. The essence of PP No. 23 of 2018 is a reduction in tariffs carried out by the Director General of Taxes to stimulate business actors to also carry out their obligations to provide contributions to the state because they earn income from their business. SME entrepreneurs also realize the importance of paying taxes awareness and knowing the sanctions that will be obtained if the SME taxpayer does not carry out their obligations when they already have an NPWP and their turnover exceeds the tax provisions. Therefore, the perception of taxpayers on tax regulations, especially PP. 23 of 2018 motivates or influences SME taxpayer compliance.

The Self Assessment System has a significant positive effect on SME taxpayer compliance. This means that the better the understanding of SMEs on the Tax Self Assessment System will increase taxpayer compliance. This has implications for the importance of understanding that SMEs that already have an NPWP must have to carry out a self-assessment of their tax obligations. The implementation of Tax Self-Assessment for SMEs requires SMEs that already have an NPWP to calculate, pay and report their tax obligations. What often happens is that SMEs when selling both trade and services related to third parties, for example, government agencies are deducted and pay taxes but have not yet arrived to report due to SMEs' ignorance regarding online reporting. The implication of this research is that it is expected that there will be socialization and assistance for SMEs to report their tax obligations online using the e-filling tax system.

The application of SME accounting and income levels does not affect the compliance of SME taxpayers in Magelang City. This means that taxpayer compliance is not influenced by the presence or absence of accounting bookkeeping or the application of accounting for SMEs and also the income level of SMEs. Taxpayer compliance is more influenced by tax laws and regulations which can force SME businesses to provide tax contributions to the state. The implication of the results of this study will be used as a service to improve taxpayer compliance of SMEs in Magelang City. 


\section{Conclusion}

Based on the results of the research conducted, it can be concluded that the following research data were used as a sample of 58 questionnaires filled out by owners / owners / managers of SMEs in Magelang City who already have a NPWP. The test results show that the Taxpayers' Perceptions of PP No. 23 of 2018 and the Self Assessment System have a significant positive effect on SME Taxpayer Compliance in Magelang City so that $\mathrm{H} 1$ and $\mathrm{H} 3$ of this study are accepted. Meanwhile, the application of accounting for SMEs and income levels has no effect on SME taxpayer compliance in Magelang City, $\mathrm{H} 2$ and $\mathrm{H} 4$ research is not accepted. The implication of this research is the importance of understanding tax regulations and knowledge of the self-assessment system for SMEs so that it will further improve compliance with paying SME taxes in a conscious manner without any coercion from regulations.

Some of the limitations of this study include the sample used is SMEs in Magelang City that already have a NPWP. Suggestions for further research are to use a sample of MSMEs registered at the Tax Service Office (KPP) as PKP to have a turnover above the tax legislation.

\section{References}

[1] Assa, Jeremiah Reinhart, Lintje Kalangi, Winston Pontoh. 2018. Pengaruh Pemeriksaan Pajak dan Sanksi Perpajakan terhadap Kepatuhan Wajib Pajak pada Kantor Pelayanan Pajak Pratama Manado. Jurnal Riset Akuntansi Going Concern 13(4) 516-522.

[2] Darmawati, Deni, Ayu Aulia Oktaviani. 2018. Pengaruh Penerapan Akuntansi UMKM terhadap Kepatuhan Wajib Pajak UMKM E-Commerce. Seminar Nasional Cendekiawan ke-4 tahun 2018 ISSN (P) 2460-8696 ISSN (E) 2540-7589

[3] Dewi, Luh Putu Santi Krisna, Ni Ketut Lely Aryani Merkusiwati.2018. Pengaruh Kesadaran Wajib Pajak, Sanksi Perpajakan, E-Filing, dan Tax Amnesty terhadap Kepatuhan Pelaporan Wajib Pajak. E-Jurnal Akuntansi Universitas Udayana Vol. 22.2 Februari (2018) ISSN: 2302-8556

[4] Fitriani, Annisa, Jeni Susyanti, M.Agus Salim. 2018. Faktor yang mempengaruhi Kepatuhan Pelaku Ekonomi Kreatif dalam Memenuhi Kewajiban Pajak (Studi pada wajib pajak milik UMKM di KPP Pratama Malang Selatan). E-Jurnal Riset Manajemen Prodi Manajemen Fakultas Ekonomi Unisma.

[5] Ghozali, Imam. 2018. Aplikasi Analisis Multivariate Dengan Program IBM SPSS 19. Semarang: Universitas Diponegoro.

[6] Lazuardini, Evi Rahmawati, Hj. Jeni Susyanti, Achmad Agus Priyono. 2018. Pengaruh Pemahaman Peraturan Perpajakan, Tarif Pajak dan Sanksi Pajak terhadap Kepatuhan Wajib Pajak UMKM (Studi pada Wajib Pajak Orang Pribadi yang terdaftar di KPP Pratama Malang Selatan). E-Jurnal Riset Manajemen Prodi Manajemen Fakultas Ekonomi Unisma. 